\title{
Neonatal renal venous and arterial thrombosis
}

\author{
Mario Motta \\ From XXI Congress of the Italian Society of Neonatology \\ Palermo, Italy. 24-26 September 2015
}

Renal vein thrombosis (RVT) is one of the more common forms of neonatal thrombosis accounting for $15-20 \%$ of systemic thromboembolism[1,2]. A median age at presentation of 2-3 days have been reported [1,3], with unilateral and bilateral involvement of renal vein in $89-72 \%$ and $28-11 \%$ of cases, respectively[4,5]. The clinical presentation of RVT consists of increased kidney size, macro- or microhematuria, reduced urine output with some degree of renal failure and thrombocytopenia. RVT in neonates is a multifactorial disease and it was associated with coagulopathy, maternal diabetes, birth asphyxia, sepsis, placement of central venous lines $(\mathrm{CVL})$ and hereditary thrombophilic factors[5,6]. In specific, FV 1691G $>$ A mutation and elevated Lp(a) concentrations are independent risk factors for the development of RVT in neonates. In non-CVL-related RVT, thrombus formation occurs in the small vessels of the kidney and may extend into the renal vein and inferior vena cava. In the neonates with CVL-related RVT, the thrombus most likely formed first in the vessel adjacent to the CVL and then extended into the kidney[4]. Renal ultrasonography shows uni- or bilateral kidney enlargement with loss of cortico-medullary differentiation and reduced or absent flow in renal vein[7]. Long-term functional complications include renal insufficiency, renal tubular dysfunction and hypertension in up to $30 \%$ of patients $[1,8]$. Controlled data on appropriate clinical management of neonatal RVT are lacking and recommendations of its treatment are based on low quality evidence. Current guidelines suggest for unilateral RVT in the absence of renal impairment or extension into the inferior vena cava, either 1) supportive care with radiologic monitoring for extension of thrombosis or 2) anticoagulation with unfractionated heparin (UFH)/ low-molecolar-weight heparin (LMWH) in therapeutic doses rather than no therapy[9]. For unilateral RVT that

Correspondence: mario.motta@spedalicivili.brescia.it

Neonatology and Neonatal Intensive Care Unit, Children's Hospital of Brescia, Italy

() Biomed Central

C 2015 Motta This is an Open Access article distributed under the terms of the Creative Commons Attribution License (http:// creativecommons.org/licenses/by/4.0), which permits unrestricted use, distribution, and reproduction in any medium, provided the original work is properly cited. The Creative Commons Public Domain Dedication waiver (http://creativecommons.org/publicdomain/ zero/1.0/) applies to the data made available in this article, unless otherwise stated. extends into the inferior vena cava, anticoagulation with UFH/LMWH for a total duration of between 6 weeks and 3 months is suggested[9]. For bilateral RVT with evidence of renal impairment, anticoagulation with UFH/LMWH or initial thrombolytic therapy with tissue plasminogen activator followed by anticoagulation with UFH/LMWH is suggested[9].

Renal artery thrombosis (RAT) in the neonate is far less common than RVT, and there is little information about its incidence. It is associated with umbilical catheters, patent ductus arteriosus and hereditary thrombophilia $[10,11]$. The clinical presentation is rather silent and renal ultrasound findings can be minimal unless Doppler imaging is used. The outcome of the affected kidneys is poor with common global atrophy. For neonates with a peripheral arterial catheter-related thrombosis, immediate removal of the catheter and UFH anticoagulation with or without thrombolysis or surgical thrombectomy and microvascular repair with subsequent heparin therapy are suggested[9].

Published: 24 September 2015

\section{References}

1. Schmidt B, Andrew M: Neonatal thrombosis: Report of a prospective Canadian and international registry. Pediatrics 1995, 96:939-943.

2. Nowak-Gottl U, von Kries R, Gobel U: Neonatal symptomatic thromboembolism in Germany: Two year survey. Arch Dis Child Fetal Neonatal Ed 1997, 76:F 163-167.

3. Bökenkamp A, von Kries R, Nowak-Göttl U, Göbel U, Hoyer PF: Neonatal renal venous thrombosis in Germany between 1992 and 1994: epidemiology, treatment and outcome. Eur J Pediatr 2000, 159:44-48.

4. Kuhle $S$, Massicotte $P$, Chan A, Mitchell L: A case series of 72 neonates with renal vein thrombosis. Data from the 1-800-NO-CLOTS Registry. ThrombHaemost 2004, 92:729-733.

5. Messinger $Y(1)$, Sheaffer JW, Mrozek J, Smith CM, Sinaiko AR: Renal outcome of neonatal renal venous thrombosis: review of 28 patients and effectiveness of fibrinolytics and heparin in 10 patients. Pediatrics 2006, 118:e 1478-1484.

6. Kosch A, Kuwertz-Bröking E, Heller C, Kurnik K, Schobess R, Nowak-Göttl U: Renal venous thrombosis in neonates: prothrombotic risk factors and long-term follow-up. Blood 2004, 104:1356-1360. 
7. Kraft $J K$, Brandão $L R$, Navarro $O M$ : Sonography of renal venous thrombosis in neonates and infants: can we predict outcome? PediatrRadiol 2011, 41:299-307.

8. Mocan H, Beattie TJ, Murphy AV: Renal venous thrombosis in infancy: long-term follow-up. PediatrNephrol 1991, 5:45-49.

9. Monagle P, Chan AK, Goldenberg NA, Ichord RN, Journeycake JM, NowakGöttl U, Vesely SK: Antithrombotic therapy in neonates and children. Antithrombotic Therapy and Prevention of Thrombosis, 9th ed: American College of Chest Physicians Evidence-Based Clinical Practice Guidelines. Chest 2012, 141(2 Suppl):e7375-801S.

10. Payne RM, Martin TC, Bower RJ, Canter CE: Management and follow-up of arterial thrombosis in the neonatal period. J Pediatr 1989, 114:853-858.

11. Proesmans W, van de Wijdeven P, Van Geet C: Thrombophilia in neonatal renal venous and arterial thrombosis. PediatrNephrol 2005, 20:241-242.

doi:10.1186/1824-7288-41-S1-A24

Cite this article as: Motta: Neonatal renal venous and arterial thrombosis. Italian Journal of Pediatrics 2015 41(Suppl 1):A24.

\section{Submit your next manuscript to BioMed Central} and take full advantage of:

- Convenient online submission

- Thorough peer review

- No space constraints or color figure charges

- Immediate publication on acceptance

- Inclusion in PubMed, CAS, Scopus and Google Scholar

- Research which is freely available for redistribution

Submit your manuscript at www.biomedcentral.com/submit
Ciomed Central 